\title{
Effect of Sex, type of feed and age at slaughter on carcass yield characteristics of japanese quails (cortunix japonica) in Malawi
}

\begin{abstract}
The study was carried out to evaluate carcass yield characteristics of Japanese quails (Cortunix japonica). A total of 120 Japanese quails were slaughtered at three (3) different ages: five, eight and eleven weeks, to compare the effects of sex, type of feed and age at slaughter on carcass yield composition. The birds were randomly allocated to two treatments based on type of feed with 60 birds ( 30 males and 30 females) in each treatment. Treatment one used commercial feed; broiler starter mash with $22.5 \%$ Crude Protein (CP), $18.7 \%$ CP layers. Treatment two used on-farm formulated feed, with $24.6 \%$ CP starter and grower, and 20.2\% CP layers. 20 quails (10 males and 10 females) from each treatment were slaughtered at the ages of five, eight and eleven weeks. Before slaughter the birds were starved overnight and then weighed individually. Thereafter, they were slaughtered, bled, scalded and plucked, eviscerated and dissected manually. Data collected included: live body weight, weight of gizzards, drum stick, thighs, heads, breast muscles, back, chilling loss, full and empty Gastrointestinal tract (GIT), wings, legs, necks, dressing out percentage, hot carcass and cold carcass weights. The results showed that sex, age and feed have significant effect $(\mathrm{P}<0.05)$ on carcass yield. The results also showed that quails at the age of 5 weeks have higher hot and cold carcass weights and higher slaughter weights at the age of 11 weeks. The results also showed significant differences $(\mathrm{P}<0.05)$ in some parts of the carcass between males and females with females having higher carcass parts than males. It was concluded that quails should be slaughtered around 5-6 weeks of age so as to obtain higher carcass yields.
\end{abstract}

Volume 2 Issue 2 - 2017

\author{
Kamija ZWalita, Jonathan Tanganyika, Steven \\ R Mussah \\ Department of Animal Science, Lilongwe University of \\ Agriculture and Natural Resources, Malawi
}

Correspondence: Steven R Mussah, Department of Animal Science, Bunda campus, Lilongwe University of Agriculture and Natural Resources Moyale Barracks, $3^{\text {rd }}$ Battalion, Malawi Defence Force, P O Box 23, Mzuzu, Malawi, Tel +265 884221 087/+265997406680, Email mussahsteven@gmail.com

Received: May 25, 2017 | Published: July II, 2017

Keywords: cold/hot carcass, on-farm, soybean, cortunix japonica

\section{Introduction}

Japanese quail is one of the smallest avian species reared for meat and egg production. ${ }^{1}$ Both quail meat and eggs are characterized by high nutritive value that is low in fat and cholesterol ${ }^{2}$ which is of particular importance considering the increasing cases of cardiovascular diseases in humans worldwide. Diversification into quail rearing which have short generation interval with low production costs provide a clear solution to animal protein shortage in developing countries including Malawi with $85 \%$ of its population living in rural areas occupied by subsistence farming. ${ }^{3}$

Nutritional protein deficiency is a major problem in developing countries such as Malawi, chicken meat and eggs which is the cheap source of animal protein in most poor resource base rural communities in the world is not able to meet the increasing demand of protein. ${ }^{4}$ Despite the human health benefits from quail products and the profitability of rearing quails as emerging non-conventional livestock in the world, most poultry farmers in developing countries have not adapted the quail rearing as a commercial livestock enterprise. This can be associated with lack of documented information about quail farming, health benefits, market for products and the small size of the bird by most farmers in Malawi and other developing countries. The study on quail carcass characteristics is important in determining the profit margins in commercial quail farming which depends largely on the number and productivity of the birds. According to Mussah and Phoya, ${ }^{5}$ Malawi poultry industry is going through a gradual change in terms of product differentiation in response to consumer demands. The cheap nutritional poultry protein is important in developing countries such as Malawi with limited protein alternative sources compared to developed countries with a wide range of protein sources. Adoption of quail rearing for commercial purposes in Malawi will improve the livelihoods of the rural communities and provide them with a cheap supply of nutritional protein; quails can easily be integrated with other conventional livestock.

\section{Materials and methods}

\section{Experimental design and study area}

The study was conducted at Animal Science Department, Bunda campus of the Lilongwe University of Agriculture and Natural Resources (LUANAR), Malawi. One hundred and twenty (120) day old quails were used in this study, where they were reared under intensive management system in cages. The quails were randomly allocated to 2 treatment groups, 60 birds in each treatment with equal number of males and females per treatment. Treatment one had $22.5 \%$ CP (starter and grower feeds) and $18.7 \% \mathrm{CP}$ (finisher and layer feeds). In treatment two on-farm formulated feed containing $24.6 \% \mathrm{CP}$ (starter and grower feeds) and $20.2 \% \mathrm{CP}$ (finisher and layer feeds) was used. A total of 20 Japanese quails (10 males and 10 females) were randomly selected and slaughtered at ages of 5, 8 and 11 weeks from each treatment. The feed ingredients included: Maize meal, soybean meal, fish meal, premix, salt, MCP, lime, 
DL-methionine and L-lysine in proportions calculated according to nutrient requirement levels of each treatment and stage of growth of the birds. After the feed was formulated samples of both feed were taken for analysis in the animal nutrition research laboratory and it was found that the starter mash feed had $7587 \mathrm{KJ}$ gross energy while the layers' mash had 6596KJ gross energy and Crude Protein (CP) was found to be $24.6 \%$ and $20.2 \%$ respectively. While the commercial feed had $22.5 \% \mathrm{CP}$ starter and $18.7 \%$ CP layers mash.

\section{Data collection}

Data which was collected at the ages of 5,8 and 11 weeks, included; live body weight, weight of gizzards, drum stick, thighs, heads, breast muscles, back, wings, legs, necks, chilling loss, feathers, full gastrointestinal tract empty gastrointestinal tract, head, kidney, dressing out percentage, hot carcass and cold carcass weights.

\section{Data analysis}

Data was analyzed using the General Linear Model (GLM) procedures of SAS 12.1.

\section{Statistical Model}

$Y_{i j k}=\mu+F_{i}+A_{j}+S_{k}+(F A)_{i k}+(F S)_{j k}+(F A S)_{i j k}+\varepsilon_{i j k}$

Where; $\mathrm{Y}_{\mathrm{ijk}}=$ Observed carcass yield characteristics

$\mu=$ Overall mean of the observation

$\mathrm{F}_{\mathrm{i}}=$ Effect of the Feed $(\mathrm{i}=1,2)$

$A_{j}=$ Effect of the age $(j=1,2,3)$

$\mathrm{S}_{\mathrm{K}}=$ Effect of the sex $(\mathrm{k}=1,2)$

$(\mathrm{FA})_{\mathrm{ij}}=$ Interaction effect of feed and age

$(\mathrm{FS})_{\mathrm{ik}}=$ Interaction effect of feed and sex

$(\mathrm{FAS})_{\mathrm{ijk}}=$ Interaction effect of feed, age and sex

$\varepsilon_{\mathrm{ijk}}=$ Random error component

\section{Results and discussions}

\section{Effect of sex on carcass yield characteristics}

Table 3 the main effect, sex, was significant $(\mathrm{P}<0.05)$ on full gastrointestinal tract (GIT) content, empty GIT content, cold carcass and gizzard \%. Female quail birds had a higher mean value than the male counterpart $(163.0 \mathrm{~g}$ Vs $148.0 \mathrm{~g})$. These results concur with studies by ${ }^{6}$ which reported that the Japanese quail is a sexually dimorphic bird with females having a larger body size than males unlike other poultry species. The quail birds showed differences in growth pattern between sexes, the males displayed slightly higher hot and cold carcasses percentages than the females $(68.4 \%$ Vs. $65.0 \%)$ and $(67.8 \%$ Vs. $64.0 \%)$ respectively. This difference could be associated with the aggressiveness of males over the females especially when reared together, the females are disadvantaged during feeding and watering. ${ }^{7}$ However, the growth pattern variation was different with the results by in which female quails produced higher carcass yields than male quails, the smaller body weight and decrease in live weight in male quails was associated with higher metabolic rates and hormonal change respectively. Musa et al. ${ }^{8}$ and Ilori et al. ${ }^{9}$ in their studies postulated that the differences in growth pattern and carcass weight in male and female quails could be due to feed metabolism/onset of fattening and differences in hormonal profile, aggressiveness and dominance especially when both sexes are reared together respectively. Other parameters (Feather (\%), Hot carcass (\%), Dress (\%), Chilling loss (\%), Drumstick (\%), Wings (\%), Liver (\%), Legs (\%), Kidney (\%), Necks (\%), Thighs (\%), Gizzard (\%), Breast $(\%)$, and Back (\%)) which showed insignificant differences could be associated with environmental and feed factors as suggested by.

Table I 24\% CP (starter and grower) formulated feed ingredients proportions

\begin{tabular}{ll}
\hline Ingredients & Amounts $\mathbf{( K g )}$ \\
\hline Maize & 53.66 \\
Soybeans & 38.99 \\
Fish meal & 5 \\
Salt & 0.1 \\
Premix & 0.3 \\
MCP & 0.02 \\
Lime & 1.7 \\
DL - Methionine & 0.15 \\
L - Lysine & 0.08 \\
Total & 100 \\
\hline
\end{tabular}

Table $220 \%$ CP (Layers mash) feed ingredients proportions

\begin{tabular}{ll}
\hline Ingredients & Amounts(Kg) \\
\hline Maize & 59.6 \\
Soybeans & 28.2 \\
Fish meal & 5.00 \\
Salt & 0.10 \\
Premix & 0.30 \\
MCP & 0.30 \\
Lime & 6.30 \\
DL - Methionine & 0.15 \\
L - Lysine & 0.10 \\
Total & 100.0
\end{tabular}

Table 3 Effect of sex on carcass yield characteristics of Japanese quails

\begin{tabular}{lllll}
\hline Sex/Attribute & Male & Female & SEM & P \\
\hline Slaughter weight (g) & 148 & 162.9 & 5.19 & 0.06 \\
Feather (\%) & 5.01 & 4.86 & 0.186 & 0.575 \\
Full GIT (\%) & $7.80^{\mathrm{a}}$ & $9.15^{\mathrm{b}}$ & 0.183 & $<0.00 \mathrm{I}$ \\
Empty GIT (\%) & $6.13^{\mathrm{a}}$ & $7.40^{\mathrm{b}}$ & 0.15 & $<0.00 \mathrm{I}$ \\
Hot carcass (\%) & 68.4 & 65.1 & 1.38 & $0.1 \mathrm{I}$ \\
Cold carcass (\%) & $67.9^{\mathrm{a}}$ & $64.0^{\mathrm{b}}$ & 1.28 & 0.057 \\
Dress (\%) & 68.4 & 62.8 & 2.09 & 0.083 \\
Chilling loss (\%) & $0.55 \mathrm{I}$ & 0.992 & 0.295 & 0.312 \\
Drumstick (\%) & 9.5 & 9.34 & 0.157 & 0.482 \\
Head (\%) & $5.21^{\mathrm{a}}$ & $4.32^{\mathrm{b}}$ & 0.236 & 0.021 \\
Heart (\%) & $0.870^{\mathrm{a}}$ & $0.748^{\mathrm{b}}$ & $0.03 \mathrm{I}$ & 0.028 \\
Wings (\%) & 10.5 & 10.5 & 0.202 & 0.768
\end{tabular}


Table Continued....

\begin{tabular}{lllll}
\hline Sex/Attribute & Male & Female & SEM & P \\
\hline Liver (\%) & $2.6 \mathrm{I}$ & 2.94 & 0.169 & 0.187 \\
Legs (\%) & 1.72 & 1.68 & 0.079 & 0.737 \\
Kidney (\%) & $\mathrm{I} .1$ & 0.992 & 0.054 & $0.18 \mathrm{I}$ \\
Necks (\%) & 9.17 & $8.8 \mathrm{I}$ & $0.4 \mathrm{II}$ & 0.543 \\
Thighs (\%) & 15.3 & 14.7 & 0.344 & 0.267 \\
Gizzard (\%) & $2.40^{\mathrm{a}}$ & $2.60^{\mathrm{b}}$ & 0.123 & 0.012 \\
\hline
\end{tabular}

ab: Means with different superscripts within rows are significantly different $(P<0.05)$

\section{Effect of age on carcass yield characteristics}

Table 4 The results show significant difference $(\mathrm{P}<0.05)$ in means of the Slaughter weight $(\mathrm{g})$, at the age of 5,8 and 11weeks, $130.6 \mathrm{~g}, 166.7 \mathrm{~g}$ and $169.0 \mathrm{~g}$ respectively. Quails will attain the best slaughter weight $(169.0 \mathrm{~g})$ at the age of 11 weeks under a good feeding management. According to Wilkkanowska et al. ${ }^{10}$ quail carcass yield characteristics are affected by age, the body weight increases with age, older birds have higher carcass weight compared to young birds. The hot and cold carcasses percentages at 5, 8 and 11 weeks were $(70.8 \%$ and $68.9 \%),(66.8 \%$ and $66.6 \%)$ and $(62.6 \%$ and $62.3 \%)$ respectively. The dressing percentage had a similar trend, $70.8 \%, 66.8 \%$ and $59.3 \%$ in weeks 5,8 and 11 weeks respectively. This indicates that at week 5 is the best age at which greater carcass yield can be realized, the dressing percentages, hot and cold carcass percentages are higher in week 5 compared to the percentages at weeks 8 and 11. Disposing the birds at this stage will therefore reduce the production costs in terms of reduced feed costs and increase the profit margins. These results are in agreement with those of ${ }^{11}$ who suggested the appropriate age to slaughter the quail bird is between 5 to 6 weeks of age. Other parameters such as Feather (\%), Full GIT (\%), Empty GIT (\%), Heart $(\%)$, Liver (\%), Gizzard (\%) showed significant differences $(\mathrm{P}<0.05)$ in relation to slaughter weight while the Drumstick (\%), Wings (\%), Legs (\%), Thighs (\%) had significant differences in relation to the cold carcass weight.

\section{Effect of feed on carcass yield characteristics}

Results in table 5 showed significant differences $(\mathrm{P}<0.05)$ on heart $\%$ and gizzard $\%$. Treatment 2 showed higher average slaughter weight with $162.2 \mathrm{~g}$ while in treatment 1 , a mean of $148.7 \mathrm{~g}$ was recorded. No significant differences $(\mathrm{P}<0.05)$ were observed in Slaughter weight $(\mathrm{g})$, Feather (\%), Full GIT (\%), Empty GIT (\%), Hot carcass (\%), Cold carcass (\%), Dress (\%), Chilling loss (\%), Drumstick (\%), Head (\%), Wings (\%), Liver (\%), Legs (\%), Kidney (\%), Necks (\%), Thighs $(\%)$, Breast muscle (\%), Back (\%). The lack of significant differences between the two treatments for these parameters showed that the feeds the quails were fed during the study did not have any effect on the carcass characteristic traits; the two feeds had small differences in their CP levels. However, in another study by ${ }^{12}$ in which two groups of Japanese quails were subjected to diets of varying dietary energy to protein ratio on productive performance and carcass characteristics had significantly different carcass yields, quails fed on higher CP diet producing higher carcass yields compared to those fed on low $\mathrm{CP}$ diet. The proportions of breast, legs, neck and back bone between treatments were significant $(\mathrm{P}<0.05)$.

\section{Effect of interactions on carcass characteristics}

Statistical analysis did not show significant differences of the interactions among the three factors (feed, sex and age), in all productive and measured vital organs of the Japanese quail.

Table 4 Effect of age on carcass yield characteristics of Japanese quails

\begin{tabular}{|c|c|c|c|c|c|}
\hline $\begin{array}{l}\text { Age/ } \\
\text { Attribute }\end{array}$ & 5 Weeks & 8 Weeks & II Weeks & SEM & $\mathbf{P}$ \\
\hline $\begin{array}{l}\text { Slaughter } \\
\text { weight }(g)\end{array}$ & $130.6^{\mathrm{a}}$ & $166.7^{b}$ & $169.0^{c}$ & 6.35 & $<0.002$ \\
\hline Feather (\%) & $5.74^{\mathrm{a}}$ & $4.47^{\mathrm{b}}$ & $4.59^{c}$ & 0.227 & $<0.004$ \\
\hline Full GIT (\%) & $9.65^{\mathrm{a}}$ & $8.31^{\mathrm{b}}$ & $7.47^{c}$ & 0.224 & $<0.001$ \\
\hline Empty GIT (\%) & $6.37^{\mathrm{a}}$ & $7.26^{\mathrm{b}}$ & $6.65^{c}$ & 0.184 & $<0.005$ \\
\hline Hot carcass $(\%)$ & $70.8^{\mathrm{a}}$ & $66.8^{\mathrm{b}}$ & $62.6^{c}$ & 0.1688 & $<0.005$ \\
\hline $\begin{array}{l}\text { Cold carcass } \\
\text { (\%) }\end{array}$ & $68.9^{a}$ & $66.6^{\mathrm{b}}$ & $62.3^{c}$ & 1.565 & $<0.001$ \\
\hline Dress (\%) & $70.8^{\mathrm{a}}$ & $66.8^{\mathrm{b}}$ & $59.3^{c}$ & 2.562 & $<0.008$ \\
\hline Chilling loss (\%) & $1.82^{\mathrm{a}}$ & $0.233^{b}$ & $0.267^{c}$ & 0.361 & $<0.009$ \\
\hline Drumstick (\%) & $10.7^{\mathrm{a}}$ & $8.79^{b}$ & $8.77^{c}$ & 0.193 & $<0.000$ \\
\hline Head (\%) & 4.82 & 5.02 & 4.46 & 0.289 & 0.631 \\
\hline Heart (\%) & $0.897^{a}$ & $0.77 I^{b}$ & $0.760^{c}$ & 0.037 & $<0.024$ \\
\hline Wings (\%) & $11.8^{\mathrm{a}}$ & $10.1^{\mathrm{b}}$ & $9.65^{c}$ & 0.248 & $<0.001$ \\
\hline Liver (\%) & $2.08^{\mathrm{a}}$ & $3.65^{b}$ & $2.59^{c}$ & 0.207 & $<0.000$ \\
\hline Legs (\%) & $1.64^{\mathrm{a}}$ & $1.80^{\mathrm{b}}$ & $1.67^{c}$ & 0.095 & $<0.261$ \\
\hline Kidney (\%) & 0.949 & 1.05 & 1.14 & 0.053 & 0.296 \\
\hline Necks (\%) & 9.15 & 8.51 & 9.3 & 0.504 & 0.382 \\
\hline Thighs (\%) & $15.9^{\mathrm{a}}$ & $14.1^{\mathrm{b}}$ & $14.9^{c}$ & 0.421 & $<0.011$ \\
\hline Gizzard (\%) & $2.86^{\mathrm{a}}$ & $2.18^{b}$ & $2.46^{c}$ & 0.150 & $<0.007$ \\
\hline Breast (\%) & 29.1 & 34.1 & 32.3 & 2.81 & 0.236 \\
\hline
\end{tabular}

abc : Means with different superscripts within rows are significantly different $(\mathrm{P}<0.05)$

Table 5 Effect of Feed on carcass yield characteristics of Japanese quails

\begin{tabular}{lllll}
\hline Feed/attribute & $\begin{array}{l}\text { Proto } \\
\text { feed }\end{array}$ & $\begin{array}{l}\text { Formulated } \\
\text { feed (T2) }\end{array}$ & SEM & P \\
\hline & (TI) & & & \\
\hline Slaughter weight (g) & 148.7 & 162.2 & 5.19 & 0.09 I \\
Feather (\%) & 4.78 & 5.08 & 0.186 & $0.28 \mathrm{I}$ \\
Full GIT (\%) & 8.38 & 8.57 & 0.183 & 0.475 \\
Empty GIT (\%) & 6.63 & 6.89 & 0.15 & 0.252 \\
Hot carcass (\%) & 67.8 & 65.7 & 1.38 & 0.306 \\
Cold carcass (\%) & 66.7 & 65.2 & 1.28 & 0.426 \\
Dress (\%) & 67.8 & 63.5 & 2.092 & 0.171 \\
Chilling loss (\%) & 1.07 & 0.474 & 0.295 & 0.18 \\
Drumstick (\%) & 9.36 & 9.49 & 0.157 & 0.573 \\
Head (\%) & 4.79 & 4.74 & 0.236 & 0.879 \\
Heart (\%) & $0.867^{\mathrm{a}}$ & $0.752^{\mathrm{b}}$ & $0.03 \mathrm{I}$ & 0.021 \\
Wings (\%) & 10.8 & 10.2 & 0.202 & 0.065 \\
Liver (\%) & 2.89 & 2.66 & 0.169 & 0.343 \\
\hline
\end{tabular}


Table Continued.

\begin{tabular}{lllll}
\hline Feed/attribute & $\begin{array}{l}\text { Proto } \\
\text { feed }\end{array}$ & $\begin{array}{l}\text { Formulated } \\
\text { feed (T2) }\end{array}$ & SEM & P \\
\hline & (TI) & & & \\
\hline Legs (\%) & 1.78 & 1.62 & 0.078 & 0.163 \\
Kidney (\%) & 1.08 & 1.01 & 0.054 & 0.358 \\
Necks (\%) & 9.09 & 8.88 & 0.411 & 0.724 \\
Thighs (\%) & 14.9 & 15.1 & 0.344 & 0.614 \\
Gizzard (\%) & $2.36^{\mathrm{a}}$ & $2.64^{\mathrm{b}}$ & 0.123 & 0.023 \\
Breast muscle (\%) & 32.9 & 31.1 & 2.3 & 0.638 \\
Back (\%) & 21.9 & 21.2 & 0.591 & 0.396 \\
\hline
\end{tabular}

abc: Means with different superscripts within rows are significantly different $(\mathrm{P}<0.05)$.

\section{Conclusion}

Carcass yield of Japanese quail is affected by several factors such as age, sex and feed. Female quail birds registered higher carcass traits than the male counter parts. Female quail birds have higher slaughter weight as compared to the males. The study concludes that the optimal age to slaughter quail birds is around 5-6 weeks. Higher carcass yields as well as hot and cold carcass percentages are realized at this age.

\section{Acknowledgements}

The authors would like to thank Mr. Joseph Kere Odero (Jomo Kenyatta University of Agriculture and Technology-Kenya) for his contributions during the preparation of this paper. Many thanks to all the workers at Bunda College Students' Farm for raising the birds used in this study.

\section{Conflict of interest}

The author declares no conflict of interest.

\section{References}

1. Panda B, Singh RP. Development in processing quail. World Poultry science. 1990;46(3):219-234.

2. Daikwo SI, Momoh OM, Dim NI. Heritability Estimates of, Genetic and phenotypic correlations among some selected carcass traits of Japanese quail (Coturnix coturnix japonica) raised in sub-humid Climate. Journal of biology, Agriculture and Healthcare. 2013;3(5).

3. National Statistical Office (NSO). Press Report on National Statistics. Zomba Malawi; 2008.

4. Oladipo FO, Olorunfemi OD, Adefalu LLM, et al. Awareness of poultry farmers on Quail production in Kwara state, Nigeria:implication for protein nutritional sustainability in Nigeria. Journal of sustainable Development in Africa. 2014:16.

5. Mussah SR, Phoya RKD. Determination of age at slaughter on meat quality characteristics for indigenous Malawian spotted (kawangi) chickens. Livestock Research for Rural Development. 2017:29(3).

6. Simeon OO. Carcass characteristics of coturnix quail as affected by sex and Housing System. International Journal of Agriculture, Forestry and Fisheries. 2015;3(3):76-79.

7. Adedeji TA, Adebambo OA, Ozoje MO, et al. Early growth performance of crossbred chickens resulting from different sire Strains. 2004.

8. Musa HH, Chen GH, Cheng JH, et al. Study on carcass characteristics of chicken breeds raised under the intensive condition. International journal of poultry sciences. 2006;5:530-533.

9. Ilori BM, Peters SO, Ikeobi CON, et al. Comparative Assessment of Growth in Pure and Crossbred Turkeys in a Humid Tropical Environment. International Journal of Poultry Science. 2010;9(4):368-375.

10. Wilkkanowska A, Kokoszyński D. Comparison of Slaughter Value in Pharaoh Quail of ages. Journal of central European Agriculture. 2011;12(1):145-154

11. Maurice Randal. Raising Japanese Quail. 2006.

12. Siyadati SM, Irani K, Ghazvinian A, et al. Effect of varying dietary energy to protein ratio on productive performance and carcass characteristics of Japanese quail. Annals of Biological Research. 2011;2:149-155. 